\title{
Knowledge, Attitude and Practice Scale of Medical Personnel on Smoking Cessation Guidelines: A Review on Associations and Questionnaires
}

Shaiful Ehsan Shalihin ${ }^{1 *}$, Mohamad Haniki NM²

\author{
1 Department of Family Medicine, \\ Kulliyyah of Medicine, \\ International Islamic University of Malaysia, \\ IIUM, Kuantan, Malaysia \\ ${ }^{2}$ Department of Pharmacy Practice, \\ Kulliyyah of Pharmacy, \\ International Islamic University of Malaysia, \\ IIUM, Kuantan, Malaysia
}

\section{*Corresponding author's email: \\ shaifulehsan@iium.edu.my}

Received: 4 November 2018

Accepted: 8 January 2019

How to Cite:

Shalihin, M. S. E., \& Nik Mohamed, M. H. (2019). Knowledge, attitude and practice scale of medical personnel on smoking cessation guidelines: A review on associations and questionnaires. Borneo Journal of Medical Sciences (BJMS), 13 (2), 3-13. Retrieved from https://jurcon.ums.edu.my/ojums/index.php/ bjms/article/view/1531

Keywords: smoking cessation, questionnaire, knowledge, attitude, practice

\section{ABSTRACT}

The number of active smokers in Malaysia is increasing despite the availability of stop smoking clinics and smoking cessation medications. Other than smokers' level of motivation to quit smoking, competency of the healthcare professionals involved in providing smoking cessation intervention using evidencebased guidelines needs to be considered. Hence, knowledge, attitude and practice (KAP) of the healthcare providers in relation to existing clinical practice guidelines on smoking cessation should be assessed. In this review, we look at the factors contributing to the KAP of medical personnel on the guidelines and also the previously available assessment tool, mainly in the form of a validated questionnaire, for the purpose of applying it to the context of the Malaysian healthcare providers.

\section{INTRODUCTION}

Globally, the prevalence of smoking is increasing in trend especially among adolescents, which led to the recent World Health Organization (WHO) action on enforcing bans on tobacco advertising, promotion and sponsorship, including the ban on selling cigarettes to minors' ${ }^{1}$. Smoking is generally five times higher among men than women; however, the gender gap declines with younger age ${ }^{2}$. The number of smokers and number of cigarettes smoked worldwide have increased tremendously ${ }^{2}$. This trend is comparable in Malaysia whereby the prevalence of current smokers has increased in trend from $21.5 \%$ in 2006 to $24.7 \%$ in 2011 , 
despite the trend reducing initially from 1996 to $2006^{3}$.

Cigarette smoking is one of the modifiable risk factors for chronic illnesses and mortality among humans ${ }^{4}$. Smoking reduces the quality of life and increases the risk of developing non-communicable diseases including coronary artery disease and chronic obstructive pulmonary disease ${ }^{4}$. Smoking also increases the risk to develop cancer of the lung, oropharynx, larynx and pancreas ${ }^{4}$. Furthermore, pregnant mothers who are active smokers will have higher chance to deliver low birth weight infants compared to non-smoker mothers ${ }^{5}$. Moreover, tobacco use increases economic and financial burden to the public and its country 4 . Worldwide, it causes more than half a trillion dollars of economic damage per year'.

About 2.3 billion people worldwide are now covered by at least one tobacco control measure at the highest level of achievement. This is due to the actions taken by many WHO Member States to fight the tobacco epidemic. However, in Malaysia, even though smoking cessation programme already existed for the past decade, the outcome of such programme is still not encouraging ${ }^{6}$. The reason for such failure remains controversial either due to lack of awareness among the public or suboptimal knowledge and less action taken by the medical personnel.

Worldwide, smoking cessation guidelines have been implemented in order to encourage and help people to stop smoking ${ }^{4}$ 7. It universally incorporated the $5 A^{\prime}$ s and $5 R$ 's components. These components are important in initiating stop smoking among smokers and maintaining their abstinence. It can be delivered not only by the physician or medical officer, but by any medical personnel, who has been trained formally. It is found to be useful in daily busy outpatient clinic setting ${ }^{4}$, 7. The 5A's components consist of 'ask', 'advice', 'assess', 'assist' and 'arrange' components which are useful on encountering any new patients ${ }^{6}$.
While, the 5R's components consist of 'relevant', 'risks', 'rewards', 'roadblocks' and 'repetitions' components. These are especially beneficial in convincing the unmotivated smoker to stop smoking ${ }^{4,7}$.

Even though these $5 A^{\prime} s$ and $5 R^{\prime} s$ components are simple and useful in stop smoking practices, the lack of its awareness and implementation is the major culprit in contributing to the increasing number of unmotivated smokers ${ }^{1,7}$. The factors associated could be due to lack of training or experience in working among the medical personnels ${ }^{9}$. So far, assessment regarding awareness and implementation of the guidelines among medical professionals in Malaysia is unknown. In addition, there is no valid questionnaire or tool available in our country to perform the assessment.

FACTORS ASSOCIATED WITH LEVEL OF KNOWLEDGE, ATTITUDE AND PRACTICE OF MEDICAL PERSONNEL ON STOP SMOKING MEASURE

Significant factors contributing to awareness and practices of smoking cessation services among medical personnel includes age, gender, profession, practice location, smoking status and history of attending formal stop smoking training. Nevertheless, having attended a smoking cessation training programme is the only significant predictor of a good practice $\mathrm{score}^{10}$. Indeed, formal training is the best way of overcoming barrier in providing stop smoking advice ${ }^{11,12}$.

Increasing age is associated with more professional experience because of increasing number of job training and abundant continuous medical education sessions ${ }^{13}$. Therefore, years of practice contributes to a higher level of expertise, knowledge and capabilities ${ }^{8,}{ }^{14}$. Male doctors are more confident in managing the case especially at their own primary care level. However, female 
medical personnel believe that they have higher confidence level and be excellent time managers while giving advice to patients ${ }^{15}$. Malay medical personnel are associated with higher prevalence of smokers in our country, in which their awareness may be low in giving stop smoking advice as well ${ }^{16}$.

Smoking will cause poor quality of life and health. Therefore, doctors who are active smokers will develop medical illness earlier. This will affect their daily performance as a medical doctor ${ }^{14,17}$. Doctors who smoke also will spend shorter duration of time in giving stop smoking counselling compared to nonsmoker doctors as they feel uncomfortable talking about stop smoking and therefore results in poor practices score $^{18}$. Area of practice also contributes to stop smoking advice $^{14}$. Less number of smokers seen in the practising area makes the health providers more comfortable and confident in giving advice compared to the place where smoking is accepted to be normal ${ }^{19}$.

Location of the government health clinic either near or far from the city could also affect the awareness and implementation of stop smoking services among practitioners. At first glance, it may seem easier to deliver tobacco preventive measure to the rural community since their population is less than that in the urban area, but the challenges are still huge as number of smokers is basically concentrated in the rural area. Rural people usually have higher poverty level and poor insight to seek attention to stop smoking which may cause difficulties for the primary care to practice the stop smoking cessation advice ${ }^{20}$.

Islam prohibits cigarette smoking and its related products. This decree or 'fatwa' can be used among Muslim doctors as the basis and fundamental input to increase the understandings and willingness of their Muslim patients to quit smoking ${ }^{21,22}$. Among all professions, family medicine specialists and trainees are competent enough to give stop smoking advice at primary care levels ${ }^{23}$. Nevertheless, in tertiary centres, internal medicine specialists are more commonly involved in stop smoking practice compared to other departments ${ }^{14}$.

\section{QUESTIONNAIRES AS INSTRUMENT TOOL ON ASSESSING LEVEL OF KNOWLEDGE, ATTITUDE AND PRACTICE OF MEDICAL PERSONNEL ON STOP SMOKING MEASURE}

We reviewed all questionnaires that had already been published in previous journals since 1990 till 2018 using keywords search of '5A's', '5R's', 'knowledge', 'attitude', 'practice' and 'questionnaire' from Google Search, Google Scholars, ScienceDirect, PubMed and other major search websites. These related articles later only will be selected if covers smoking cessation guidelines or training programme.

In Malaysia, for the past 40 years, the studies conducted thus far are mainly limited to smoking behaviour, attitude and opinions towards smoking habit and competency of giving stop smoking advice, rather than on the awareness and practices of both $5 A^{\prime}$ 's and $5 R^{\prime}$ s framework ${ }^{16,20,24}$. These studies also were mainly done among medical students. Furthermore, studies on the practice of smoking cessation counselling are mainly limited among dentists and nurses rather than on medical doctors ${ }^{25,26}$.

The common tool that was used in previous studies worldwide to assess knowledge, attitude and practice on stop smoking is mainly self-administered questionnaire involving cross-sectional study design ${ }^{22,23}$. Despite the lack of locally validated questionnaire, lbrahim et al., in 2008 conducted a study on attitude and practice among dentists in Kelantan using a self-administered questionnaire ${ }^{25}$. It gathered background data of the dentists, their attitude on smoking cessation, 5A's practices in smoking cessation and their barriers in smoking cessation 
practices $^{26}$. However, the questionnaire did not include the knowledge and 5R's components of universal smoking cessation guidelines. The socioeconomic components were also inadequate in which the smoking status and background training of the respondents were not included. Similar studies have been done in our country by Vaithilingam et al., in 2012 utilizing a self-administered questionnaire that had been developed and validated by two Dental Public Health specialists and pretested with a sample of 10 dental lecturers from the University of Malaya ${ }^{26}$. However, the questionnaire did not assess the knowledge of the dentists on 5A's and 5R's components in stop smoking measures (Table 1).

Table 1 Beliefs and practices components of questionnaire used in the study by Vaithilingam et al. ${ }^{26}$

\begin{tabular}{|l|l|l|}
\hline Components & Questions or statements & Answers or responses \\
\hline $\begin{array}{l}\text { Beliefs on smoking cessation } \\
\text { intervention }\end{array}$ & $\begin{array}{l}\text { 1. Dentists should take a greater role } \\
\text { 2. Role of dental auxiliaries } \\
\text { 3. Smoke-free zone is effective }\end{array}$ & Agree / disagree \\
\hline Practices & $\begin{array}{l}\text { 1. Record smoking status on first visit } \\
\text { 2. Advice about smoking cessation to all patients who } \\
\text { smoke }\end{array}$ & Yes / no / sometimes \\
& $\begin{array}{l}\text { 3. Advice patients on hazards of smoking and benefits } \\
\text { of quitting the habit } \\
\text { 4. Provide self-help material } \\
\text { 5. Recommend nicotine replacement aids } \\
\text { 6. Refer to smoking cessation clinic } \\
\text { 7. Follow up patient on subsequent visit }\end{array}$ & \\
\hline
\end{tabular}

Worldwide, similar trend of questionnaires could be seen. Nagle et al. (1999) used a self-administered questionnaire which was piloted and validated to assess knowledge, attitude and practice of nurses on smoking cessation ${ }^{15}$. Although details regarding background of the nurses were not included, the questionnaire did include the enquiry of smoking cessation training. It assessed the knowledge of the nurses, not only on smoking but also on the cessation strategies and the appropriate pathway. However, it did not cover the 5R's components, which are vital in universal smoking cessation program.

About 10 years later, Yan et al. (2008) conducted a similar study using a selfadministered questionnaire to all healthcare providers in Changsha City ${ }^{14}$. The questionnaire was developed and validated before the actual study. However, 5R's components were not included in the survey tool. Other studies that were subsequently done in China include the study by Jiang et al. (2007) and Klink et al. $(2011)^{9}, 23$. The assessment tool is the validated questionnaire which is targeted to the physicians. Similar to the other studies, $5 R$ 's components were not included in the questionnaires.

In India, Singh et al. (2014) conducted a similar study using a validated selfadministered questionnaire among medical students and young doctors who were working or trained at various medical colleges at Delhi University ${ }^{11}$. It did cover the respondents' smoking status, history of receiving formal training in smoking cessation and general knowledge on smoking. However, the specific $5 A^{\prime}$ 's and 5R's components of smoking cessation were not clearly included in the knowledge, attitude and practice domains. The questions were mainly on the preparedness of giving smoking cessation advice and opinions on its enforcement ${ }^{11}$.

In the Middle East, Sabra (2007) conducted a study on smoking attitude, behaviour and risk perception among primary healthcare personnel in four urban 
family medicine centres in Alexandria, Egypt $^{8}$. The study utilized a well-constructed questionnaire which was modified from available questionnaire (WHO Global Health Professionals Survey (GHPS)) and Queen's University Family Medicine Development Program in the Balkans Region. The questionnaire covered the demographic background of the healthcare personnel (including smoking status and stop smoking training) and the attitude of healthcare personnel on smoking cessation and their preparedness in giving service. However, the knowledge and practices of 5R's components were not included in this questionnaire. Similar questionnaire also had been adapted by Eldein et al. (2012) among family physicians in Suez Canal University, Egypt ${ }^{13}$.

Similar studies had been done in North American and African country. For example, Desalu et al. (2009) conducted a cross-sectional study on smoking cessation measures among physicians in Nigeria ${ }^{27}$. Questions were mainly revolving at the mode of treatment given and barriers in implementing smoking cessation measures. Another similar study was done by La Torre et al. (2014) but enquired more on the use of antidepressants (Bupropion or Zyban ${ }^{\circledast}$ ) and acetylcholine receptor partial agonists (Varenicline or Champix $^{\circledR}$ ) as part of smoking cessation intervention in the questionnaire ${ }^{28}$.

In the western countries, a larger sample size was covered using well-structured questionnaire. In 2010, Tong et al. conducted a national survey in the United States on the health professionals' smoking prevalence, smoking cessation practices and their beliefs on smoking cessation ${ }^{29}$. This study used pretested questionnaire of 2002 New Jersey Health Care Provide Tobacco Study as their instrument tool. It consists of demographic data of the health professionals, their beliefs on the smoking cessation and their practices of $5 A^{\prime}$ 's components of stop smoking. Nevertheless, the knowledge on 5A's and 5R's components was not assessed. The attitude and practice of 5R's components were also not covered. Similar studies also had been done subsequently by Dymek in 2013 and Prucha et al. among pharmacists in Poland ${ }^{24,30}$. However, the questionnaires still have similar limitations.

The only questionnaire that includes both 5A's and 5R's components in its assessment is used by Alzoubi in $2010^{22}$. It had been developed and validated in a pilot study. However the questionnaire is rather superficial and unable to differentiate lies by the respondents as it gives feedback based on 'yes' or 'no' answers. This questionnaire also does not consist of all the three components of knowledge, attitude and practice ${ }^{22}$. The knowledge component only contains two simple questions of "Did you know 5A's" and "Did you know 5R's" which are indeed in a form of statement and thus was unable to assess overall knowledge. In addition, it is also unable to provide questions specific to the knowledge components of 5A's and 5R's. The questionnaire only highlighted the practice of the components without including the attitude domain (Table 2). 
Borneo Journal of Medical Sciences 13 (2) May, 2019: 3-13

Table 2 Knowledge, 5A's and 5Rs components of the questionnaire used in the study by Alzoubi et al. ${ }^{22}$

\begin{tabular}{|c|c|c|}
\hline Components & Questions & Answers \\
\hline Knowledge & $\begin{array}{l}\text { 1. Are you concerned about the importance of cigarette cessation? } \\
\text { 2. Do you know the } 5 A^{\prime} \text { 's of smoking cessation guidelines? } \\
\text { 3. Do you know the } 5 \text { R's of motivational interventions of smoking } \\
\text { cessation guidelines? }\end{array}$ & Yes/ no/ somewhat \\
\hline 5As practices & $\begin{array}{l}\text { 1. Do you advise him/her to quit? } \\
\text { 2. Do you assess his/her willingness to quit? } \\
\text { 3. Do you assist him/her with a quitting plan? } \\
\text { 4. Do you provide him/her with a supportive clinical environment } \\
\text { while encouraging his/her quitting attempt? } \\
\text { 5. Do you help the patient to develop social support for his/ her quitting } \\
\text { attempt in his/her environment outside of treatment? } \\
\text { 6. Do you recommend the use of effective pharmacotherapy that is } \\
\text { available? } \\
\text { 7. Do you arrange for follow-ups of his/her quitting? }\end{array}$ & Yes/no/ somewhat \\
\hline 5R's practices & $\begin{array}{l}\text { 1. Do you promote motivation to quit? } \\
\text { 2. Do you encourage him/her to indicate why quitting is personally } \\
\text { relevant? } \\
\text { 3. Do you ask him/her to identify any potential risks or negative } \\
\text { consequences of smoking? } \\
\text { 4. Do you ask him/her to identify or reward any potential benefits of } \\
\text { quitting? } \\
\text { 5. Do you ask him/her to identify barriers to quitting? } \\
\text { 6. Do you ask him/her to identify any possible complications of } \\
\text { treatment? } \\
\text { 7. Do you maintain ongoing motivation for your patient every visit? }\end{array}$ & Yes/ no/ somewhat \\
\hline
\end{tabular}

As a whole, previous questionnaires lack a proper scoring system in terms of assessing the cumulative points for combination of knowledge, attitude and practices (KAP) domains of the stop smoking guidelines ${ }^{22}$. With the exception of the study done by Eldein et al. in 2013, the other questionnaires only give results in terms of frequency rather than definitive value of high or low KAP score ${ }^{13}$. The major differences of previous questionnaires are summarized in Table 3. 
Table 3 Differences of questionnaires done in previous study on smoking cessation measures

\begin{tabular}{|c|c|c|c|c|c|}
\hline $\begin{array}{l}\text { Questionnaire } \\
\text { (Research } \\
\text { Authors) }\end{array}$ & $\begin{array}{l}\text { Demographic } \\
\text { data }\end{array}$ & $\begin{array}{l}\text { Presence of } \\
\text { Knowledge, } \\
\text { Attitude } \\
\text { and Practice } \\
\text { domain } \\
\end{array}$ & $\begin{array}{c}5 A^{\prime} \text { s and } 5 R s \\
\text { components coverage }\end{array}$ & Methods & $\begin{array}{c}\text { Validated } \\
\text { Questionnaire }\end{array}$ \\
\hline $\begin{array}{l}\text { Nagle et al. } \\
(1999)^{15}\end{array}$ & Adequate & Yes & $\begin{array}{l}\text { 1. Ask smoking status } \\
\text { 2. Take smoking history } \\
\text { 3. Assess intentions to } \\
\text { quit } \\
\text { 4. Discuss how to quit }\end{array}$ & $\begin{array}{l}\text { Study done in } \\
\text { Australia among } \\
\text { volunteered } \\
\text { nurses using } \\
\text { self-administered } \\
\text { questionnaire }\end{array}$ & Yes \\
\hline $\begin{array}{l}\text { Yan et al. } \\
(2008)^{14}\end{array}$ & Adequate & Yes & $\begin{array}{l}\text { 1. Ask smoking status } \\
\text { 2. Assess willingness to } \\
\text { quit } \\
\text { 3. Advice smokers to quit } \\
\text { 4. Arrange plan to quit }\end{array}$ & $\begin{array}{l}\text { Using a self- } \\
\text { administered } \\
\text { questionnaire } \\
\text { to healthcare } \\
\text { providers in } \\
\text { Changsha City, } \\
\text { China. }\end{array}$ & Yes \\
\hline Sabra $(2007)^{8}$ & Yes & $\begin{array}{l}\text { No knowledge } \\
\text { domain }\end{array}$ & $\begin{array}{l}\text { 1. Ask smoking status } \\
\text { 2. Assess intentions to } \\
\text { quit } \\
\text { 3. Advice smokers to quit } \\
\text { 4. Discuss how to quit } \\
\text { 5. Arrange plan to quit }\end{array}$ & $\begin{array}{l}\text { Study on } \\
\text { smoking attitude, } \\
\text { behaviour and risk } \\
\text { perception among } \\
\text { primary healthcare } \\
\text { personnel in four } \\
\text { urban family } \\
\text { medicine centres } \\
\text { in Alexandria, } \\
\text { Egypt }\end{array}$ & $\begin{array}{l}\text { Modified from } \\
\text { validated } \\
\text { questionnaire }\end{array}$ \\
\hline $\begin{array}{l}\text { Ibrahim et al. } \\
(2008)^{25}\end{array}$ & $\begin{array}{l}\text { No smoking } \\
\text { status }\end{array}$ & $\begin{array}{l}\text { No knowledge } \\
\text { domain }\end{array}$ & $\begin{array}{l}\text { 1. Do you enquire about } \\
\text { your patient's smoking } \\
\text { status? } \\
\text { 2. Do you offer smoking } \\
\text { cessation counselling to } \\
\text { your patients? } \\
\text { 3. Do you explain to } \\
\text { patients regarding } \\
\text { the health risks due to } \\
\text { smoking? } \\
\text { 4. Do you provide advice } \\
\text { or helpful hints to } \\
\text { motivate patients to } \\
\text { quit smoking? } \\
\text { 5. Do you provide reading } \\
\text { materials on smoking } \\
\text { cessation in your } \\
\text { waiting area? }\end{array}$ & $\begin{array}{l}\text { Study on attitude } \\
\text { and practice } \\
\text { among dentists in } \\
\text { Kelantan using a } \\
\text { self-administered } \\
\text { questionnaire }\end{array}$ & Yes \\
\hline $\begin{array}{l}\text { Desalu et al. } \\
(2009)^{27}\end{array}$ & Yes & $\begin{array}{l}\text { No knowledge } \\
\text { domain }\end{array}$ & No & $\begin{array}{l}\text { A cross-sectional } \\
\text { study on smoking } \\
\text { cessation } \\
\text { measures among } \\
\text { physicians in } \\
\text { Nigeria }\end{array}$ & No \\
\hline $\begin{array}{l}\text { Alzoubi et al. } \\
(2010)^{22}\end{array}$ & Yes & $\begin{array}{l}\text { Superficial } \\
\text { knowledge } \\
\text { domain, } \\
\text { no attitude } \\
\text { domain }\end{array}$ & $\begin{array}{l}\text { Items of ask, advice, } \\
\text { assess, assist, arrange, } \\
\text { relevance, risks, rewards, } \\
\text { roadblocks and repetition }\end{array}$ & $\begin{array}{l}\text { A cross-sectional } \\
\text { study using self- } \\
\text { administered } \\
\text { questionnaire } \\
\text { among healthcare } \\
\text { providers in } \\
\text { Jordan. }\end{array}$ & Yes \\
\hline
\end{tabular}




\begin{tabular}{|c|c|c|c|c|c|}
\hline $\begin{array}{l}\text { Tong et al. } \\
(2010)^{29}\end{array}$ & Yes & $\begin{array}{l}\text { No knowledge } \\
\text { domain }\end{array}$ & $\begin{array}{l}\text { 1. Ever ask if patient } \\
\text { smokes. } \\
\text { 2. Advises smokers to stop } \\
\text { smoking. } \\
\text { 3. Assesses smokers if } \\
\text { interested in quitting. } \\
\text { 4. Assists smokers to quit. } \\
\text { 5. Sets quit date. } \\
\text { 6. Refer cessation } \\
\text { program. } \\
\text { 7. Provides material with } \\
\text { quit-line information8. } \\
\text { Discuss medication } \\
\text { 9. Arranges follow-up }\end{array}$ & $\begin{array}{l}\text { National survey in } \\
\text { the United States } \\
\text { on the health } \\
\text { professionals' } \\
\text { smoking } \\
\text { prevalence, } \\
\text { smoking cessation } \\
\text { practices and their } \\
\text { beliefs on smoking } \\
\text { cessation. }\end{array}$ & Yes \\
\hline $\begin{array}{l}\text { Klink et al. } \\
(2011)^{23}\end{array}$ & Yes & $\begin{array}{l}\text { No knowledge } \\
\text { domain }\end{array}$ & $\begin{array}{l}\text { Items of ask, advice, } \\
\text { assess, assist, arrange, }\end{array}$ & $\begin{array}{l}\text { Cross-sectional } \\
\text { study using } \\
\text { validated } \\
\text { questionnaire } \\
\text { targeted to the } \\
\text { community } \\
\text { healthcare } \\
\text { providers in China. }\end{array}$ & $\begin{array}{l}\text { Modified } \\
\text { from validate } \\
\text { questionnaire }\end{array}$ \\
\hline $\begin{array}{l}\text { Vaithilingham } \\
\text { et al. }(2012)^{26}\end{array}$ & Adequate & $\begin{array}{l}\text { No knowledge } \\
\text { domain }\end{array}$ & $\begin{array}{l}\text { 1. Able to ask about } \\
\text { smoking in an } \\
\text { appropriate way. } \\
\text { 2. Able to advice patient } \\
\text { to quit smoking. } \\
\text { 3. Able to ask appropriate } \\
\text { questions to assess } \\
\text { readiness to make a } \\
\text { quit attempt } \\
\text { 4. Able to assist patient to } \\
\text { quit smoking } \\
\text { 5. Able to arrange proper } \\
\text { follow up with patient }\end{array}$ & $\begin{array}{l}\text { Cross-sectional } \\
\text { study using self- } \\
\text { administered } \\
\text { questionnaire } \\
\text { among } \\
\text { periodontists and } \\
\text { dentists that had } \\
\text { been developed } \\
\text { and validated by } \\
\text { two Dental Public } \\
\text { Health specialists } \\
\text { and pre-tested } \\
\text { with a sample } \\
\text { of } 10 \text { dental } \\
\text { lecturers from } \\
\text { the University of } \\
\text { Malaya. }\end{array}$ & Yes \\
\hline $\begin{array}{l}\text { Dymek et al. } \\
(2013)^{24}\end{array}$ & Yes & Yes & No & $\begin{array}{l}\text { Cross-sectional } \\
\text { study assessing } \\
\text { knowledge of } \\
\text { pharmacist in } \\
\text { Poland. }\end{array}$ & No \\
\hline $\begin{array}{l}\text { Eldein et al. } \\
(2013)^{13}\end{array}$ & Yes & Yes & $\begin{array}{l}\text { Self-reported frequency } \\
\text { of use of the } 5 \text { As tobacco } \\
\text { cessation guidelines - ask, } \\
\text { advice, assess, assist and } \\
\text { arrange. }\end{array}$ & $\begin{array}{l}\text { A cross-sectional } \\
\text { study among } \\
\text { family physicians } \\
\text { in Suez Canal } \\
\text { University, Egypt. }\end{array}$ & Yes \\
\hline Singh $(2014)^{11}$ & Yes & Yes & No & $\begin{array}{l}\text { Study using a } \\
\text { validated self- } \\
\text { administered } \\
\text { questionnaire } \\
\text { among medical } \\
\text { students and } \\
\text { young doctors } \\
\text { who were working } \\
\text { or trained at } \\
\text { various medical } \\
\text { colleges at Delhi } \\
\text { University India. }\end{array}$ & Yes \\
\hline
\end{tabular}




\begin{tabular}{|c|c|c|c|c|c|}
\hline $\begin{array}{l}\text { La Torre et al. } \\
(2014)^{28}\end{array}$ & Yes & Yes & No & $\begin{array}{l}\text { Assessing use of } \\
\text { antidepressants } \\
\text { (Bupropion or } \\
\text { Zyban }^{\circledR} \text { ) and } \\
\text { acetylcholine } \\
\text { receptor } \\
\text { partial agonists } \\
\text { (Varenicline or } \\
\text { Champix }{ }^{\circledast} \text { ) as } \\
\text { part of smoking } \\
\text { cessation } \\
\text { intervention } \\
\text { among public } \\
\text { health trainees in } \\
\text { Italy. }\end{array}$ & Yes \\
\hline $\begin{array}{l}\text { Prucha et al. } \\
(2015)^{30}\end{array}$ & Yes & Yes & $\begin{array}{l}\text { 1. Do you ask about } \\
\text { tobacco use? } \\
\text { 2. Do you advise } \\
\text { patients to quit using } \\
\text { tobacco? } \\
\text { 3. Do you advise female } \\
\text { patients to quit using } \\
\text { tobacco if they are } \\
\text { pregnant? } \\
\text { 4. Do you advise patients } \\
\text { if you think an illness is } \\
\text { related to tobacco use? } \\
\text { 5. Do you advise patients } \\
\text { to have smoke-free } \\
\text { homes? } \\
\text { 6. Do you advise patients } \\
\text { to have smoke-free } \\
\text { vehicles? } \\
\text { 7. Do you advise patients } \\
\text { to quit using tobacco if } \\
\text { they are healthy? } \\
\text { 8. Do you assist tobacco } \\
\text { users to quit? } \\
\text { 9. Do you advise patients } \\
\text { if you do not think } \\
\text { an illness is related to } \\
\text { tobacco use? }\end{array}$ & $\begin{array}{l}\text { Study using self- } \\
\text { administered } \\
\text { questionnaire } \\
\text { on knowledge, } \\
\text { attitude and } \\
\text { practice among } \\
\text { healthcare workers } \\
\text { in Republic } \\
\text { Dominican. }\end{array}$ & No \\
\hline
\end{tabular}

\section{CONCLUSION}

The main obstacle and difficulty of measuring knowledge, attitude and practice (KAP) of medical personnel on smoking cessation guidelines are basically lack of an accurate and comprehensive assessment tool in the form of questionnaire. Most available questionnaires do not include the 5R's components (relevance, risks, rewards, roadblocks and repetition) in their items and lack of proper cumulative values in order to interpret the KAP score. The 5R's components are indeed important in motivating the unmotivated smokers to quit. Meanwhile, low KAP scores are mainly contributed by lack of available smoking cessation training or programme in their centres. Therefore, we suggest new questionnaire development consisting of knowledge, attitude and practice domains of smoking cessation guidelines including all $5 A^{\prime}$ 's and 5R's components. Furthermore, more smoking cessation training programme and continuous education session on smoking should be provided to medical personnel. 


\section{ACKNOWLEDGEMENTS}

The authors would like to thank and show their gratitude to family medicine specialists in Kuantan for sharing their pearls of wisdom during the course of this review article.

\section{CONFLICT OF INTEREST}

The authors declare that they have no competing interests in publishing this article.

\section{REFERENCES}

1. World Health Organization. Prevalence of tobacco use. Global Health Observatory Data. WHO [Online. Accessed 15 February, 2015]. Available at http://www.who.int/gho/ tobacco/use/en/

2. $\mathrm{Ng} \mathrm{M}$, Freeman $M K$, Fleming TD et al. (2014). Smoking prevalence and cigarette consumption in 187 countries, 1980 - 2012. Journal of American Medical Association 311 (1): $83-92$.

3. Institute of Public Health. (2011). National Health Morbidity Survey IV. NHMS Fact Sheet.

4. Michael CF, Carlos RJ et al. (2008). Treating tobacco use and dependence: 2008 update. U.S. Public Health Service Clinical Practice Guideline Executive Summary. Respiratory Care 53 (9): 1217 - 1222. Retrieved from bphc.hrsa.gov/buckets/treatingtobacco.pdf

5. Norsa'adah B, Salinah O. (2014). The effect of second-hand smoke exposure during pregnancy on the newborn weight in Malaysia. The Malaysian Journal of Medical Sciences 21 (2): $44-53$.

6. Lim HK, Ghazali SM, Kee CC et al. (2013). Epidemiology of smoking among Malaysian adult males: Prevalence and associated factors. BMC Public Health 13: 8. DOI: 10.1186/1471-2458-13-8

7. Malaysia, Ministry of Health. (2017). Clinical practice guidelines on treatment of tobacco use and dependence 2017. Academy of Medicine of Malaysia.

8. Sabra AA. (2007). Smoking attitudes, behaviours and risk perceptions among primary health care personnel in urban family medicine centers in Alexandria. Journal Egypt Public Health Association 82: 43 - 64.
9. Jiang Y, Ong MK, Tong EK et al. (2007). Chinese physicians and their smoking knowledge, attitudes, and practices. American Journal of Preventive Medicine 33: 15 - 22.

10. Pipe A, Sorensen M, Reid R. (2009). Physician smoking status, attitudes toward smoking, and cessation advice to patients: an international survey. Patient Education and Counselling 74 (1): $18-23$.

11. Singh S, Sinha SK, Saha R, Jha M, Kataria DK. (2014). Knowledge, attitude and practice related to tobacco use and its cessation among young medical professionals. Indian Journal of Social Psychiatry 30: 35 - 42.

12. Katz DA, Paez MW, Reisinger HS et al. (2014). Implementation of smoking cessation guidelines in the emergency department: a qualitative study of staff perceptions. Addiction Science \& Clinical Practice 9 (1).

13. Eldein HN, Mansour NM, Mohamed SF. (2013). Knowledge, attitude and practice of family physicians regarding smoking cessation counseling in family practice centers, Suez Canal University, Egypt. Journal of Family Medicine and Primary Care 2 (15): 9.

14. Yan J, Xiao S, Ouyang D et al. (2008). Smoking behavior, knowledge, attitudes and practice among health care providers in Changsha city, China. Nicotine \& Tobacco Research 10 (7): $37-44$.

15. Nagle A, Schofield M, Redman S. (1999). Australian nurses' smoking behaviour, knowledge and attitude towards providing smoking cessation care to their patients. Health Promotion International 14 (1): 33 - 44.

16. Maniam T, Muda JR. (1996). Smoking habits in a general practice sample. Medical Journal of Malaysia 51 (22): 2 - 6.

17. Sadowski IJ, Ruffieux C, Cornuz J. (2009). Self-reported smoking cessation activities among Swiss primary care physicians. BMC Family Practice 10 (22). DOI: 10.1186/14712296-10-22.

18. Vogt F, Hall S, Marteau TM. (2005). General practitioners' and family physicians' negative beliefs and attitudes towards discussing smoking cessation with patients: A systematic review. Journal of Addiction 100 (14): $23-31$.

19. Shadel WG, Elliott MN, Haas AC et al. (2015). Clinician advice to quit smoking among seniors. Preventive Medicine 70 (8): 3 - 9.

20. Supramaniam V. (1980). Habits and attitudes of Malaysian military doctors towards smoking. Med J Malaysia 34 (3): 205 - 210. 
21. JabatanKemajuan Islam Malaysia. Merokok Dari Pandangan Islam - Portal Rasmi Fatwa Malaysia. [Retrieved 14 March, 2015]. Available from http://www.e-fatwa.gov. my/fatwa-kebangsaan/merokok-daripandangan-islam

22. Alzoubi KH, Azab M, Khabour OF et al. (2010). Smoking-cessation practice guidelines: awareness and implementation among medical teams. International Journal of Pharmacy Practice 18 (9): 3 - 9.

23. Klink K, Lin S, Elkin Z, Strigenz D, Liu S. (2011). Smoking cessation knowledge, attitudes, and practice among community health providers in China. Journal of Family Medicine 43 (19): 8.

24. Dymek J, Skowron A. (2013). Assessment of pharmacists' knowledge and competence regarding anti-tobacco counselling. Journal of Pharmacy 1 (2): 48 - 55.

25. Ibrahim H, Norkhafizah S. (2008). Attitudes and practices in smoking cessation counselling among dentists in Kelantan. Archives of Orofacial Sciences 3 (1): 1 - 6.

26. Vaithilingam RD, Noor NMM, Mustafa R, Taiyeb-Ali TB. (2012). Practices and beliefs among Malaysian dentists and periodontists towards smoking cessation intervention. Sains Malaysiana 41 (93): 1 - 7.
27. Desalu OO, Adekoya AO, Elegbede AO et al. (2009). Knowledge of and practices related to smoking cessation among physicians in Nigeria. Jornal Brasileiro de Pneumologia 35 (1): 198 - 203.

28. La Torre G, Saulle R, Unim B et al. (2014). Knowledge, attitudes, and smoking behaviours among physicians specializing in public health: A multicentre study. BioMed Research International: $1-8$.

29. Tong EK, Strouse $R$, Hall J, Kovac $M$, Schroeder SA. (2010). National survey of US health professionals' smoking prevalence, cessation practices, and beliefs. Nicotine \& Tobacco Research 12 (7): 24 - 33.

30. Prucha MG, Fisher SG, Mclntosh $S$ et al. (2015). Health care workers' knowledge, attitudes and practices on tobacco use in economically disadvantaged Dominican Republic communities. International Journal of Environmental Research and Public Health 12 (40): $60-75$. 
